\title{
BERIMAN DALAM KESUNYIAN
}

\author{
Oleh: Raja Oloan Tumanggor \\ rajat@fpi.untar.ac.id \\ Fakultas Psikologi Universitas Tarumanagara Jakarta
}

\begin{abstract}
Abstrak
Beriman itu memiliki konsekwensi dan resiko. Mengamalkan iman menjadi tujuan setiap pemeluk agama. Namun kadang timbul masalah, karena tidak bisa mengungkapkan dan mempraktekkan iman itu secara terang-terangan karena berbagai hal. Berhadapan dengan situasi tersebut memang tidak ada jalan lain selain dengan beriman dalam kesunyian.
\end{abstract}

Film Silence garapan sutradara kawakan Martin Scorsese yang sedang tayang di bioskop saat ini menceritakan mengenai dua misionaris Jesuit asal Portugal yang berkarya di Jepang pada abad ke17. Film yang diangkat dari novel berjudul sama karya novelis Katolik Jepang Shusako Endo ini menggambarkan pergulatan iman kedua misionaris Rodriques dan Garupe di tengah-tengah sekelompok orang Jepang yang secara diam-diam memeluk agama Katolik.

Orang Katolik hidup dalam tekanan kaum Samurai. Mereka dikejar-kejar dan disiksa agar menyangkal imannya. Akan tetapi dalam diam warga tetap bertahan dengan keyakinannya. Kedua misionaris melihat betapa berat siksaan dan derita yang dialami umatnya dalam mempertahankan iman.

Melalui film ini tergambar pola beriman kedua misionaris yang mempertanyakan iman di tengah beragam tekanan. Mengapa Tuhan sepertinya diam saja saat umat-Nya dianiaya? Namun di sisi lain umat yang hidup dalam kemiskinan dan kesulitan malahan tetap pasrah dan berpegang teguh pada iman dengan harapan akan kehidupan kekal abadi di surga.

Beriman di tengah beragam tekanan dan cobaan kerap menimbulkan tanda tanya. Apakah Tuhan tidak melihat penderitaan dan kesulitan yang dialami umat-Nya? Kalau Dia melihatnya mengapa penderitaan dan kesulitan itu tetap dibiarkan berlangsung? Ketiadaan jawaban kerap dirasa menyakitkan dan kadang sampai pada sebuah kesimpulan: Jangan-jangan berdoa kepada-Nya sebuah kesia-siaan.

Ada tiga gagasan yang bisa ditarik dari Silence. Pertama, dalam konteks film ini muncul gambaran Tuhan yang seakan diam terhadap situasi umat yang teranianya. Kedua, di pihak lain umat yang miskin dan teranianya ini tetap setia dan kuat dengan imannya, kendatipun itu semua harus dihayati dalam kebisuan. Ketiga, umat atau bahkan gembala yang tidak kuat dengan penganianyaan dan cobaan terpaksa menanggalkan imannya, tapi sebetulnya tidak pernah benar-benar menanggalkan kepercayaannya kepada Tuhan dan tetap menghayatinya dalam kesunyian.

Pengalaman beriman ala Silence ini sebetulnya cerminan dari realitas keberimanan orang Kristen sepanjang masa. Dalam sejarah kekristenan para pengikut Kristus kerap mengalami pengejaran. Sejak umat perdana hingga kekristenan menyebar ke kaisaran Romawi orang Kristen tidak luput dari derita dan penganianyaan. Hingga saat ini di berbagai belahan dunia orang Kristen harus berjuang mempertahankan imannya di tengah gelombang penindasan dan kekerasan. 
Di tengah pergulatan itu orang Kristen dihadapkan pada dua pilihan: dapat hidup dengan melepaskan iman kristianinya atau mati karena imannya. Banyak orang Kristen harus kehilangan nyawa karena imannya akan Kristus, tapi tidak sedikit juga memilih menanggalkan imannya untuk menghindari penganianyaan.

Dalam perspektif penghanyatan iman secara pribadi, beriman dalam kesunyian dapat dipahami sebagai pengalaman padang gurun. Dalam derap kehidupan sehari-hari terkadang muncul perasaan ditinggalkan Tuhan, misalnya penyakit yang mendera tiada henti, kegagalan dalam karir dan rumah tangga, kekosongan batin, dll. Pada situasi seperti ini masih adakah kata 'setia' dalam iman?

Beriman dalam kesunyian juga dialami saudara-saudari kita di tanah air. Di beberapa tempat di negeri ini tidak begitu gampang untuk beribadah di rumah pribadi sekali pun karena semakin meningkatnya kelompok radikal dan intoleransi. Ada juga yang tetap bertahan dengan imannya kendati harus beribadah di bawah tenda, karena kesulitan memperoleh ijin pendirian rumah ibadah. Tidak sedikit juga mengalami hambatan dalam karir baik dalam profesi maupun di kancah politik hanya karena imannya.

Mereka yang tidak kuat dengan penganianyaan dan penindasan ini kadang harus menyerah dengan meninggalkan imannya. Kesetiaan kepada iman kristianinya menjadi goyah apalagi saat diimingimingi dengan jabatan dan kehormatan yang menggiurkan.

Beriman dalam kesunyian membutuhkan kesetiaan dan komitmen, karena Tuhan pada dasarnya tidak pernah diam, tapi terus berkarya dengan cara-Nya sendiri untuk menyertai umat-Nya sampai akhir zaman. Dan, itu jelas terungkap dalam keseluruhan kisah pergulatan iman orang Katolik Jepang dalam film Silence. 